\title{
RESOURCE MANAGEMENT OF INDUSTRIAL REGIONS
}

\author{
Ye. V. Terekhov, Ph. D (Econ.), Associate Professor, Dnipro University of Technology, \\ eugen-ter@ukr.net,orcid.org/0000-0002-4816-6072 \\ V. A. Shapoval, Ph. D (Econ.), Associate Professor, Dnipro University of Technology, \\ vadim_shapoval@ukr.net,orcid.org/0000-0003-3603-9348 \\ Yu. I. Litvinov, Ph. D (Tech.), Associate Professor, Dnipro University of Technology, \\ litvinovyuriy82@gmail.com,orcid.org/0000-0002-1801-6719
}

Methods. The problem of studying resource constraints in industrial regions should be considered from the standpoint of assessing the negative effects of production activities on the elements of the environment and determining the role of natural resources in meeting the development needs of the region. The formation of a competitive region should be based on identifying ways to improve the efficiency of its resource management.

Results. Modern problems of resource provision of production activity in industrial regions are determined. It is established that the specifics of the use of local production resources of the industrial region is their faster depletion and deterioration of environmental characteristics in future economic periods. An analysis of the practice of using certain types of production resources and their relationship in achieving economic growth in the region. Ways to increase the efficiency of economic resources of industrial regions are identified.

Novelty. The study is based on the presentation of all production resources of industrial regions as a single territorial base, the deterioration of the characteristics of which in relation to the resource needs of the region is possible even for the violation of a single production resource. Therefore, the management of production resources of industrial regions should provide a common concept of improving their efficiency.

Practical value. The results of the study can be used in planning areas of local economic development and assessing the resource potential of industrial regions.

Keywords: production resources, industrial region, natural resources, regional development, resource management.

Statement of problem. In the context of globalization of economic processes and rapid demographic changes, not only companies but also regions compete for valuable resources to achieve their growth goals. In order to increase the attractiveness of a particular business location and, thus, create incentives for companies to establish high-tech industries, it is necessary to know the strengths and weaknesses of the region, rational use of their available resources [1]. Resource constraints are particularly pronounced in industrial regions due to the use of natural resources, due to the much higher level of man-made load in these regions on the elements of the environment compared to the national average.
Analysis of recent papers. Analysis of recent research and publications. Climate change, and with it urbanization, industrial development and the use of raw materials, intensification of other economic activities cause serious environmental problems. Consequences of varying severity depend on the geographical region of Europe. These regional differences must be taken into account in environmental measures [2]. Resource constraints are becoming increasingly apparent, especially for industrial regions [3]. Jeremias Herberg notes the importance of overcoming the contradictions between resource needs and the modalities of meeting them at the regional level [4].

(C) 2021. Ye. V. Terekhov, V. A. Shapoval, Yu. I. Litvinov. Published by Dnipro University of Technology on behalf of Economics bulletin of the Dnipro University of Technology. This is an Open Access article distributed under the terms of the Creative Commons Attribution License (http: // creativecommons.org/licenses/by/4,0/), which permits unrestricted reuse, distribution and reproduction in any medium provided the original work is property cited 
M. Heidenreich, J. Mattes point to the need to study the features of innovative activity of enterprises in the region in the efficient use of its resources [5].

Thus, the problem of determining the ways of rational use of economic resources of industrial regions requires further research in terms of deteriorating their environmental performance and increasing competition in the resource market.

Aim of the paper. The purpose of the article is to assess the problems of using the economic resources of industrial regions and identify ways to overcome their resource constraints in order to achieve sustainable regional development.

Materials and methods. Natural resources are the material, energy and spatial basis for the development of industry. In addition, the natural environment serves not only as a resource base at the input of the production system, but also absorbs a variety of production wastes that accumulate at the output of production systems. The use of natural resources throughout the value chain is always linked to the burden on the environment, and the level of consumption of these resources around the world is growing steadily.

It is the industries that cause the greatest damage to the natural environment, which are most concentrated in regions with pronounced industrial specialization. In the table. 1 shows data on the distribution of pollutants due to activities by economic activity.

5 regions (Dnipropetrovsk, Donetsk, Zaporizhia, Kharkiv regions, Kyiv) account for more than $50 \%$ of the gross value added of the processing industry. At the same time, the total gross value added of the processing industry of such 5 regions as Zakarpattia, Ternopil, Luhansk, Kherson and Chernivtsi regions does not exceed $5.5 \%$

Table 1

Emissions of pollutants into the atmosphere

from stationary sources of pollution, thousand tons

\begin{tabular}{|l|c|c|c|}
\hline \multirow{2}{*}{\multicolumn{1}{|c|}{ Types of economic activity }} & \multicolumn{3}{c|}{ Year } \\
\cline { 2 - 4 } & 2018 & 2019 & 2020 \\
\hline Agriculture, forestry and fisheries & 78,2 & 82,1 & 64,1 \\
\hline Mining industry & 445,1 & 418,9 & 365,6 \\
\hline Processing industry & 882,9 & 890,3 & 868,8 \\
\hline Electricity supply & 988 & 960,7 & 849,2 \\
\hline Water supply, sewerage, waste management & 16,2 & 18,9 & 17,4 \\
\hline Construction, trade & 7,6 & 5,9 & 5,1 \\
\hline Transport, warehousing & 58,2 & 53,9 & 45,6 \\
\hline
\end{tabular}

Thus, in the regions where the objects of extractive industry, processing industry, electric power industry are concentrated, there is the greatest pollution of the environment, which worsens the quality of natural resources and the possibility of their further involvement in production.

The main local resources for economic development of the industrial region should include:

1. Land resources;

2. Human resources;

3. Energy resources;

4. Water resources.

An important resource for the development of various types of management is land resources, which serve as a territorial basis for the location of production facilities, as well as a source of raw materials. In industrial regions, the development of industry is inevitably associated with the withdrawal of land that was previously in other types of land use, and, above all, through the withdrawal of agricultural land. In 2020, the area of agricultural land was $68.5 \%$ against $72 \%$ in 2000. This indicates a significant reduction in the area of salt-land as a result of the use of land for other purposes, and in particular for the development of industry. Further development of this trend may jeopardize the country's satisfactory security and reduce the use of land as a means of production. 
To rationalize land use in industrial regions, it is necessary to conduct an inventory of land and identify areas with reduced productive properties, which should primarily be subject to alienation, to introduce production technologies aimed at reducing land consumption of products, to carry out measures for reclamation and cleaning. lands from pollutants, etc.

In accordance with the goals of sustainable development of Ukraine until 2030 [6] it is necessary to pay attention to the development of agriculture, greening of relevant production processes, ensuring the availability and sustainable management of water resources, ensuring access to inexpensive, reliable and renewable sources energy.
The annual flow of fresh water in Ukraine per capita is about 1 thousand $\mathrm{m} 3$, which indicates a low level of water supply of the country (for example, Germany - 2,278 thousand m3, Spain $-2,390$ thousand m3, Canada -100 thousand $m 3$ [7]). To preserve water resources in industrial regions, it is necessary to introduce closed technological cycles of water use, to install filters for purification of polluted waters, to use biological methods of water resources purification.

The structure of electricity production in Ukraine also does not meet European standards due to the significant share of fossil sources (Table 2)

Structure of electricity production in Ukraine by sources, billion kWh

\begin{tabular}{|l|l|l|l|l|l|l|}
\hline Year & 2015 & 2016 & 2017 & 2018 & 2019 & 2020 \\
\hline Electricity generation, total & 157,7 & 154,8 & 155,4 & 159,4 & 154,0 & 148,9 \\
\hline including & & & & & & \\
\hline Thermal power plants of Ukraine GC & 49,4 & 49,9 & 45,0 & 47,8 & 44,9 & 39,6 \\
\hline Thermal power plant & 6,1 & 6,7 & 10,9 & 11,0 & 10,9 & 12,8 \\
\hline Hydroelectric power station & 5,2 & 7,5 & 9,0 & 10,4 & 6,5 & 6,0 \\
\hline Hydroaccumulating power plant & 1,6 & 1,6 & 1,6 & 1,6 & 1,3 & 1,6 \\
\hline Nuclear power plant & 87,6 & 81,0 & 85,6 & 84,4 & 83,0 & 76,2 \\
\hline Block stations & 6,2 & 6,6 & 1,5 & 1,5 & 1,8 & 1,8 \\
\hline $\begin{array}{c}\text { Alternative energy sources (WPP, SES, } \\
\text { Biomass) }\end{array}$ & 1,6 & 1,6 & 1,9 & 2,6 & 5,5 & 10,9 \\
\hline \multicolumn{2}{|l|}{ Source: Ministry of Energy and Coal [8] } & & & & & \\
\hline
\end{tabular}

Thus, over the years, TPPs account for about $30 \%$ of electricity generation, which indicates a significant carbonization of the process of covering the energy needs of industry. Further development of alternative energy sources will allow energy modernization of industry and save non-renewable regional resources.

These types of regional development resources can be used effectively if each of them is available in sufficient quantities. The deficit of one of them will violate the rational balance of resources to meet the needs of industrial production.

The transition to a new energy and raw material base does not only concern the specialized sector. We are talking about the ecological modernization of industry in general - but especially about those industries that impose a disproportionate burden on the environment and resources, measured in terms of their added value and service life of their products. These are: energy sector, mining industry, vehicle construction, chemical industry, air traffic, etc.

The use of raw materials in the region significantly depends on the quantitative and qualitative composition of its labor resources, which are characterized by increasing mobility.

It should be noted that the economic development of territorial communities and the country as a whole is determined by the content and efficiency of the use of relevant labor, its 
availability and potential. Depending on many different factors, in particular the common in a particular region of the country economic activities, the nature and scale of business projects, is the formation of the local labor market. For existing enterprises with a high level of complexity of business processes, it is important to be flexible and systematic in solving problems of meeting their own staffing needs under conditions of uncertainty. These accents especially concern the industrial enterprises of the industrial regions.

It is important for the development of personnel strategy at the enterprise is the understanding of its management that the concept of "labor force" covers both employed and unemployed people aged 15 years. According to the State Statistics Service of Ukraine, in 2020 the labor force in Ukraine amounted to 17.7 million people (-0.5 million people compared to the previous year). A common stereotype among employers is the assumption of a strong desire of the local unemployed to be employed by the company in the event of job vacancies, for example, created due to staff turnover. To eliminate this stereotype, the company's management must take into account that only part of the population of the group forms the labor supply, so it is employed (16 million people in 2020) or can be recognized as unemployed (1.7 million people in 2020). The main characteristics of the unemployed population, to which they pay undue attention, are the following: no job; actively looking for work; ready to start work in the next two weeks. Thus, part of the population is not part of the labor force (14.4 million people in 2020). According to the State Statistics Service of Ukraine [9], among the causes of unemployment in 2020, the population of Ukraine aged 15 and older:

- retirement age $65.3 \%$ to the corresponding age category;

- status of pupil and student - $15.2 \%$;

- fulfillment of domestic (family) responsibilities and / or maintenance - $16.3 \%$;

- despair in the process of finding a job $0.3 \%$
- belief in the lack of suitable work and inability to look for work $-0.4 \%$;

- other reasons $-2.6 \%$.

In this case, the importance for the workforce, more important than the industry affiliation of the enterprise, is its reputation as an employer that will provide adequate working conditions, in particular for groups without the status of «labor». Among other important factors in the formation of the labor market in Ukraine: increasing the age of the population; external migration of young people for education and employment; deteriorating health of the population; low motivation for economic activity through employment in local «traditional» industrial enterprises with low ratings as an employer.

Meeting the needs of industrial enterprises in personnel may include: implementation of training programs for personnel by the enterprise itself; compensation of staff costs for professional training in educational institutions; measures to find and conclude an employment agreement with specialists already employed at other enterprises; measures to ensure labor migration of personnel, etc. Based on the above set of measures for human resource management, the cost part of the economy of the enterprise is formed, which is based on the following processes: search, evaluation and selection of candidates for jobs; staff training and adaptation; remuneration and social insurance of staff; payment of compensation payments to staff. Therefore, companies need to be balanced in the content of card strategy and cost management related to the use of human resources.

Consider some aspects and trends in staffing enterprises in the industrial regions of Ukraine. The most industrially developed is the Prydniprovsky economic region, which generates Dnipropetrovsk and Zaporizhia oblasts on average 14\% [10] of the country's GDP, second only to the capital - Kyiv (Fig. 1). Due to the occupation of the Russian Federation, the former competitor of the Prydniprovsky economic district in this rating - Donetsk district - reduced its contribution to the country's GDP 
to $6.2 \%$, which is less than the Kharkiv region from the North-Eastern region [10]. Note that the city of Kyiv among the considered industrial centers of Ukraine has a significant difference from other regions - the city is characterized by a high share of services and other economic activities, which reduces the contribution of industrial enterprises to the overall business results.

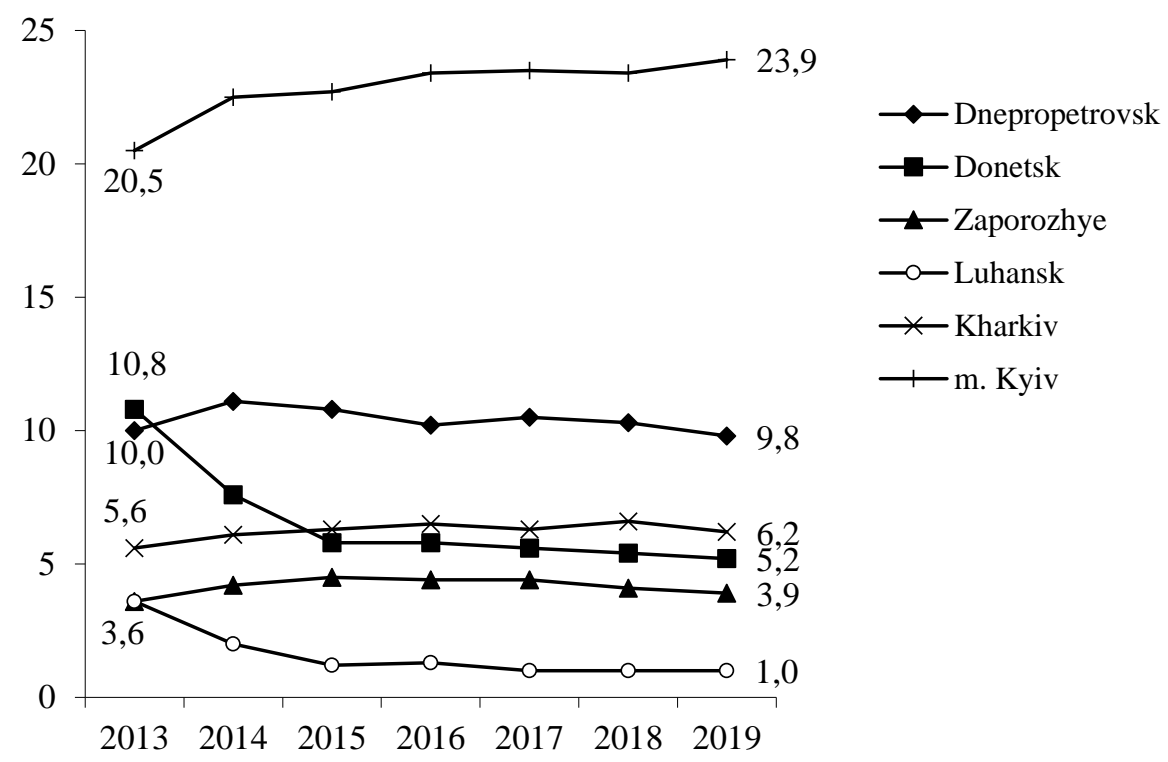

Fig. 1. Dynamics of the share of gross regional product of industrial regions of Ukraine in total (selectively by years), \%. Built by the authors according to the data [10]

Regional GDP is provided by the activities of employees, the number of which in the traditional industrial regions of the country is declining (Table 3), including those that have not been occupied by part of their territory. The number of employees for the period 2013-2019 decreased by $11.9 \%$ in Dnipropetrovsk region, by $8-9 \%$ in Zaporizhia and Kharkiv regions [11]. This trend can be explained by the natural and migratory movement of the population, which chooses more attractive regions and places. The city of Kyiv has been and remains a powerful center of attraction for the workforce, which is looking for the best opportunities for selfrealization, in particular, outside the industrial sphere of economic activity. Thus, the attractiveness of the capital of Ukraine for internal migrants poses a certain threat to local labor markets. In addition, the existing precedents and trends of increasing loyalty of foreign governments, primarily EU countries [12], to Ukrainian migrants further confirm the likelihood of a scenario of reducing the number of labor in the regions of Ukraine.
Table 3

Dynamics of the number of employees in the industrial regions of Ukraine (selectively), 2013-2019. Built by the authors according to [12]

\begin{tabular}{|l|c|c|}
\hline $\begin{array}{c}\text { Region / city of } \\
\text { Ukraine }\end{array}$ & $\begin{array}{c}\text { Number } \\
\text { of people }\end{array}$ & $\begin{array}{c}\text { Dynamics of } \\
\text { changes, } \%\end{array}$ \\
\hline Dnipropetrovsk & -87108 & $-11,9$ \\
\hline Donetsk & -576381 & $-67,9$ \\
\hline Zaporizhia & -25597 & $-8,9$ \\
\hline Luhansk & -267671 & $-80,4$ \\
\hline Kharkiv & -40228 & $-9,3$ \\
\hline m. Kyiv & 236386 & 15,7 \\
\hline
\end{tabular}

Despite the development of Ukrainian medium-sized businesses as a powerful employer, large enterprises remain a capacious source of jobs in the industrial regions of Ukraine (Fig. 2). For example, in the Dnipropetrovsk region, $39.3 \%$ of employees 
work at large enterprises. Medium business is the largest employer in the Kharkiv region $61.4 \%$ of employees are employed. Given the distribution of enterprises by their size, we note that, in terms of business sustainability as a system, medium-sized businesses tend to tend to small businesses. In particular, when considering current issues, challenges and measures to support enterprises, the group small and medium business (SME). This approach is associated with different potentials and risks of addressing the issues of providing human resources for business development programs by enterprises of different sizes..

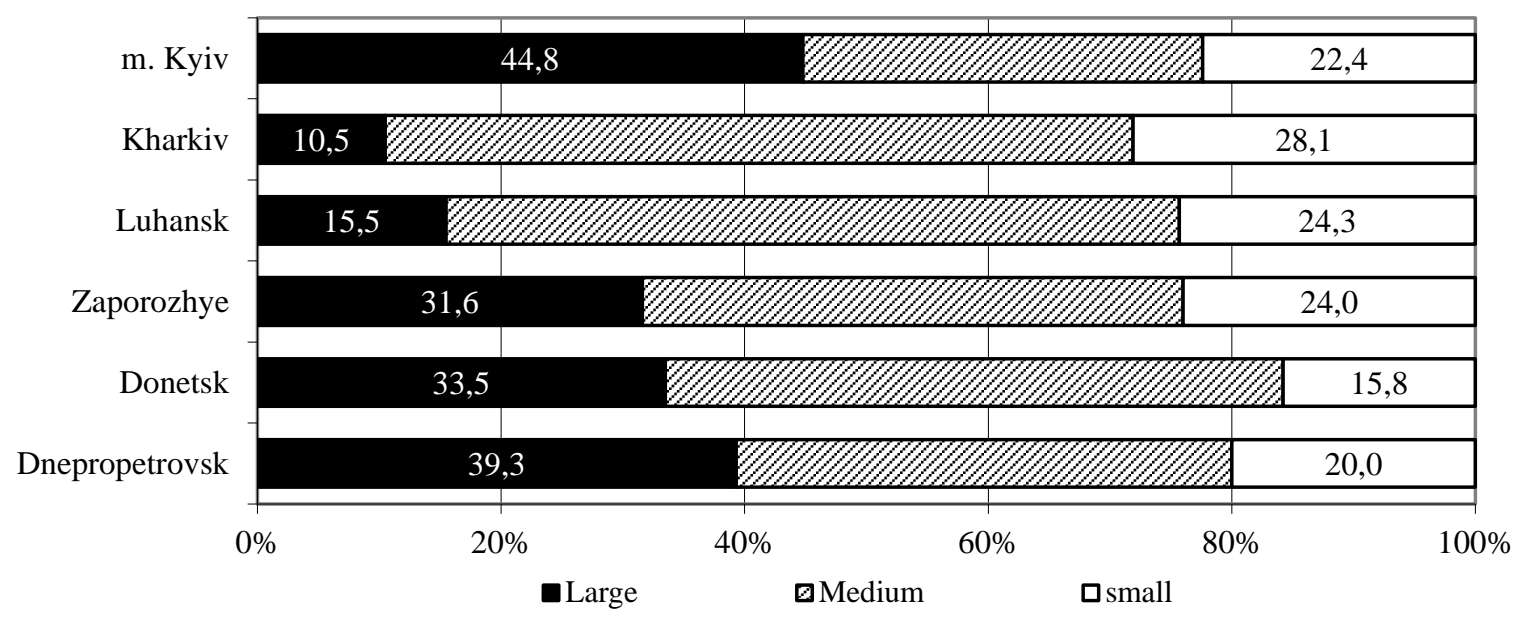

Fig. 2. The structure of employees with the division into large, medium and small enterprises of the regions of Ukraine in 2019 (selectively), \%. Built by the author according to [12]

The general trend is an increase in personnel costs of enterprises in industrial regions [13]. At the same time, the specific costs - costs per person - are different (Table 4). The undisputed leader in terms of costs is the city of Kyiv, but among the traditional industrial regions, the largest costs are large and mediumsized enterprises of Dnipropetrovsk region, respectively 154.9 and 123.9 thousand $\mathrm{UAH}$. per employee. Common medium-sized enterprises in the Kharkiv region have significantly higher personnel costs compared to large enterprises. Personnel costs of large enterprises in Zaporizhia region and, especially, Kharkiv region, are several times less than the corresponding costs of similar enterprises in Dnipropetrovsk region, which may indicate more effective human resource management.

Table 4

Specific personnel costs of enterprises in the regions of Ukraine with the division into large, medium and small enterprises in 2019 (selectively), thousand UAH Built by the author according to [13]

\begin{tabular}{|l|c|c|c|}
\hline \multicolumn{1}{|c|}{ Region / city of Ukraine } & Large & Medium & small \\
\hline Dnipropetrovsk & 154,9 & 123,9 & 80,5 \\
\hline Donetsk & 71,6 & 69,3 & 26,7 \\
\hline Zaporizhia & 56,2 & 47,0 & 37,0 \\
\hline Luhansk & 4,7 & 16,9 & 9,3 \\
\hline Kharkiv & 20,1 & 105,2 & 66,4 \\
\hline Kyiv city & 489,3 & 397,7 & 338,0 \\
\hline
\end{tabular}


Thus, modern industrial enterprises in the industrialized regions of Ukraine have a number of urgent tasks in the context of the formation of their personnel strategies to meet the needs of business development programs. A sound principle of this strategy, in our opinion, is to promote the preservation of the staff given the limited and risky migration of local labor, the high cost of efforts of enterprises to retain qualified personnel, which will increase their loyalty to the employer.

Conclusions. Comprehensive and economical use of the main types of natural resources of industrial regions should be based on organizational approaches and technological solutions that limit the primary violation and provide for multiple use of raw materials in production cycles, implementation of recycling schemes for industrial waste. In principle, industrial waste should be considered as a raw material source for the manufacture of products at the regional level, the supply of which could reduce the resource needs of the local level and allow to diversify the economic activities of the region. Gradual change in the economic structure of industrial regions in the direction of organizing environmental entrepreneurship can reduce the resource deficit and create an alternative to the resource-intensive nature of regional development.

Thus, the availability of urgent tasks in the formation of personnel strategies at modern enterprises in the industrialized regions of Ukraine should meet the needs of business in qualified personnel. This can be achieved by harmonizing the efforts to preserve the staff, taking into account the high cost of the efforts of the employer.

\section{Література}

1. Dr. Eva M. Brüning. Ressourcenausstattung als strategischer Erfolgsfaktor der Regionalentwicklung. Eine Analyse am Beispiel der Europäischen Metropolregion Rhein-Neckar. Verlag: Springer Fachmedien Wiesbaden. 2012. Pp. 173-175.

2 Umwelt und natürliche Ressourcen. URL:https://www.interreg.de/INTERREG2014/DE/Inter reg/UnsereThemen/UmweltundNatuerlicheRessourcen/u mweltundnatuerlicheressourcen-node.html.
3. Ressourcennutzung und ihre Folgen. URL: https://www.umweltbundesamt.de/themen/abfallressourcen/ressourcennutzung-ihre-folgen

4. Herberg, J.; Kamlage, J.-H.; Gabler, J.; Goerke, U.; Gürtler, K.; Haas, T.; Löw Beer, D.; Luh, V.; Knobbe, S.; Reinermann, J.; Staemmler, J.; Venghaus, S. (2020): Partizipative Governance und nachhaltiger Strukturwandel. Zwischenstand und Handlungsmöglichkeiten in der Lausitz und im Rheinischen Revier, IASS Broschüre, Potsdam.

5. Heidenreich, M., and J. Mattes. 2019. «Regionale Innovationssysteme und Innovationscluster.» In Handbuch Innovationsforschung, edited by B. BlättelMink, I. Schulz-Schaeffer, and A. Windeler, 117. Heidelberg: Springer.

6. Про цілі сталого розвитку України на період до 2030 року: Указ Президента України від 30 вересня 2019 р. № 722/2019. Офіційний вісник України. 2019. № 79. [Електронний ресурс]. Режим доступу: https://www.president.gov.ua/documents/7222019$\underline{29825 .}$.

7. Grundwasser in Deutschland. Bundesministerium für Umwelt, Naturschutz und Reaktorsicherheit (BMU) August 2008.

8. Україна у цифрах статистичний Збірник 2020 Київ . Державна служба статистики України, 2021. $46 \mathrm{c}$.

9. Особи, які не входять до складу робочої сили за статтю, типом місцевості, за причинами незайнятості у 2020 році. URL: http://www.ukrstat.gov.ua/operativ/operativ2020/rp/eans/ onsrs_tmpn_20_ue.xls

URL:

10. Валовий регіональний продукт (2004-2019).

http://www.ukrstat.gov.ua/operativ/operativ2020/vvp/vrp /vrp2019_ue.xls

11. Кількість найманих працівників на підприємствах з розподілом на великі, середні, малі та мікропідприємства по регіонах (2010-2019). URL: http://www.ukrstat.gov.ua/operativ/operativ2019/fin/pdp _reg/knp_ek_vsmm_reg_2010_2019_u.xlsx

12. Останні тренди трудової міграції: Польща лідер в $\quad$ СC. 08.12.2020. URL: https://www.ukrinform.ua/rubric-economy/3150437ostanni-trendi-trudovoi-migracii-polsa-lider-v-es.html

13. Витрати на персонал підприємств 3 розподілом на великі, середні, малі та мікропідприємства по регіонах (2010-2019). URL: http://www.ukrstat.gov.ua/operativ/operativ2019/fin/pdp _reg/vpp_ek_vsmm_reg_2010_2019_u.xlsx

\section{References}

1. Dr. Eva M. Brüning. Ressourcenausstattung als strategischer Erfolgsfaktor der Regionalentwicklung. Eine Analyse am Beispiel der Europäischen Metropolregion Rhein-Neckar. Verlag: Springer Fachmedien Wiesbaden. 2012. Pp. 173-175. doi.org/10.1007/978-3-658-234058_7

2 Umwelt und natürliche Ressourcen Retrieved from https://www.interreg.de/INTERREG2014/DE/Interreg/U 
nsereThemen/UmweltundNatuerlicheRessourcen/umwelt undnatuerlicheressourcen-node.html.

3. Ressourcennutzung und ihre Folgen. Retrieved from https://www.umweltbundesamt.de/themen/abfallressourcen/ressourcennutzung-ihre-folgen

4. Herberg, J.; Kamlage, J.-H.; Gabler, J.; Goerke, U.; Gürtler, K.; Haas, T.; Löw Beer, D.; Luh, V.; Knobbe, S.; Reinermann, J.; Staemmler, J.; \& Venghaus, S. (2020): Partizipative Governance und nachhaltiger Strukturwandel. Zwischenstand und Handlungsmöglichkeiten in der Lausitz und im Rheinischen Revier, IASS Broschüre, Potsdam.

5. Heidenreich, M., and J. Mattes. 2019. «Regionale Innovationssysteme und Innovationscluster.» In Handbuch Innovationsforschung, edited by B. BlättelMink, I. Schulz-Schaeffer, and A. Windeler, 117. Heidelberg: Springer.

6. «Pro tsili saloho rozvytku Ukrainy na period do 2030 roku»: Ukaz prezydenta Ukrainy vid 30 veresnia 2019 r. № 722/2019. Ofitsiynyy visnyk Ukrainy. 2019. № 79. Retrieved

from https://www.president.gov.ua/documents/7222019-29825 7. Grundwasser in Deutschland. Bundesministerium für Umwelt, Naturschutz und Reaktorsicherheit (BMU) August 2008.

8. Ukraina u tsyfrakh. Statystychnyy zbirnyk 2020. [Ukraine in figures 2020]. (2021). Kyiv: Derzhavna sluzhba Statystyky Ukrainy.

9. «Osoby, yaki ne vkhodiat do skladu robochoyi syly za stattyu, typom mistsevosti, za prychynamy nezayniatosti u 2020 rotsi» [Persons who are not part of the labor force by sex, type of area, due to unemployment in 2020]. Retrieved from http://www.ukrstat.gov.ua/operativ/operativ2020/rp/eans/ onsrs tmpn 20 ue.xls

10. «Valovyy rehionalnyy produkt (2004-2019)» [Gross regional product (2004-2019)]. Retrieved from http://www.ukrstat.gov.ua/operativ/operativ2020/vvp/vrp /vrp2019_ue.xls

11. «Kilkist naimanykh pratsivnykiv na pidpryiemstvakh za vydamy ekonomichnoi diialnosti z rozpodilom na velyki, seredni, mali ta mikropidpryiemstva» [Number of employees in enterprises by type of economic activity with division into large, medium, small and micro enterprises]. Retrieved from

http://www.ukrstat.gov.ua/operativ/operativ2019/fin/pdp _reg/knp_ek_vsmm_reg_2010_2019_u.xlsx

12. «Ostanni trendy trudovoyi mihratsiyi: Polshcha - lider v ES» [Recent trends in labor migration: Poland is the leader in the EU] Retrieved from https://www.ukrinform.ua/rubric-economy/3150437ostanni-trendi-trudovoi-migracii-polsa-lider-v-es.html 13. «Vytraty na personal pidpryyemstv $\mathrm{z}$ rozpodilom na velyki, seredni, mali ta mikropidpryyemstva po rehionakh (2010-2019)» Retrieved from http://www.ukrstat.gov.ua/operativ/operativ2019/fin/pdp reg/vpp_ek_vsmm_reg_2010_2019_u.xlsx

\section{РЕСУРСНИЙ МЕНЕДЖМЕНТ ІНДУСТРІАЛЬНИХ РЕГІОНІВ \\ C. В. Терехов, к. е. н., доиент, НТУ «Дніпровська політехніка», \\ В. А. Шаповал, к. е. н., дочент, НТУ «Дніпровська політехніка», Ю. І. Літвінов, к. т. н., НТУ «Дніпровська політехніка»}

Методологія дослідження. Проблему дослідження ресурсних обмежень в промислових регіонах необхідно розглядати з позиції оцінки негативних наслідків виробничої діяльності на елементи довкілля та визначення ролі природних ресурсів у задоволенні потреб розвитку регіону. Формування конкурентоспроможного регіону повинне грунтуватись на визначенні шляхів підвищення ефективності його ресурсного менеджменту.

Результати. Визначені сучасні проблеми ресурсного забезпечення виробничої діяльності у промислових регіонах. Встановлено, що специфіка використання локальних виробничих ресурсів індустріального регіону полягає у їх більш швидкому вичерпанні та погіршенні екологічних характеристик у майбутніх господарських періодах. Проведено аналіз практики використання окремих видів виробничих ресурсів та їх взаємозв'язок у досягненні економічного зростання регіону. Визначені шляхи підвищення ефективності використання економічних ресурсів промислових регіонів.

Новизна. Дослідження грунтується на представленні усіх виробничих ресурсів промислових регіонів як єдиного територіального базису, погіршення характеристик якого стосовно ресурсних потреб регіону $є$ можливою навіть за порушення окремо взятого виробничого ресурсу. Тому управління виробничими ресурсами промислових регіонів повинне передбачати спільну концепцію підвищення ефективності їх використання.

Практична значущість. Результати дослідження можуть використовуватись при плануванні напрямів місцевого економічного розвитку та оцінці ресурсних можливостей індустріальних регіонів. 
Ключові слова: виробничі ресурси, промисловий регіон, природні ресурси, регіональний розвиток, ресурсний менеджмент.

РЕСУРСНЫЙ МЕНЕДЖМЕНТ ИНДУСТРИАЛЬНЫХ РЕГИОНОВ

Е. В. Терехов, к. э. н., дочент, НТУ «Днепровская политехника»,

В. А. Шаповал, к. э. н., доцент, НТУ «Днепровская политехника», Ю. И. Литвинов, к. т. н., НТУ «Днепровская политехника»

Методология исследования. Проблему исследований ресурсных ограничений в промышленных регионах необходимо рассматривать с позиции оценки негативных последствий производственной деятельности на элементы окружающей среды и определение роли природных ресурсов в удовлетворении потребностей развития региона. Формирование конкурентоспособного региона должно основываться на определении путей повышения эффективности его ресурсного менеджмента.

Результаты. Определены современные проблемы ресурсного обеспечения производственной деятельности в промышленных регионах. Установлено, что специфика использования локальных производственных ресурсов индустриального региона заключается в их более быстром исчерпании и ухудшении экологических характеристик в будущих периодах хозяйственной деятельности. Проведен анализ практики использования отдельных видов производственных ресурсов и их взаимосвязь в достижении экономического роста региона. Определены пути повышения эффективности использования экономических ресурсов промышленных регионов.

Новизна. Исследование основывается на представлении всех производственных ресурсов промышленных регионов как единого территориального базиса, ухудшение характеристик которого относительно ресурсных потребностей региона возможна даже при нарушении отдельно взятого производственного ресурса. Поэтому управление производственными ресурсами промышленных регионов должно предусматривать общую концепцию повышения эффективности их использования.

Практическая значимость. Результаты исследования могут использоваться при планировании направлений местного экономического развития и оценке ресурсных возможностей индустриальных регионов.

Ключевые слова: производственные ресурсы, промышленный регион, природные ресурсы, региональное развитие, ресурсный менеджмент.

Надійшла до редакиіï 02.03.21 p. 